\title{
THE USE OF E-SABAK IN MATHEMATICS LEARNING TO OPTIMIZE HIGHER-ORDER THINKING SKILLS
}

\author{
Muhammad Fajri ${ }^{1}$ \\ SDN Pondok Petir 01, Indonesia ${ }^{1}$ \\ E-mail: guru.penulis.fajri27@gmail.com ${ }^{1}$ \\ DOI: $\underline{10.14421 / \text { al-bidayah.v12i1.318 }}$
}

\begin{abstract}
This study aims to describe the using of e-sabak in optimizing the higher-order thinking skills in mathematics learning. The obtaining data on the description of mathematics learning through the use of esabak in optimizing higher-order thinking skills, this research applied a qualitative approach with a descriptive method. The research instrument utilized observation and documentation guidelines to photograph mathematics learning in optimizing the ability to think at a higher level through the use of esabak in fourth-grade students at Public Elementary School (or called SDN) of SDN Pondok Petir 01, Depok City. The results showed: (1) students were happy with new experiences in the use of e-sabak; (2) the use of e-sabak devices can optimize the ability of students to analyze and evaluate phenomena through observation by capturing them using e-sabak; (3) teacher provided the ways of communicating observations in front of the class to students; (4) the ability of students to create a problem-solving context still needs to be optimized through the praxis of learning in the classroom context. This study concluded that the e-sabak device helps the implementation of mathematics teaching to maximize the ability of high-level thinking students in fourth grade SDN Pondok Petir 01, Depok City.
\end{abstract}

\section{Keywords: e-sabak; mathematics learning; higher-order thinking skills}

\section{INTRODUCTION}

The use of technology-oriented learning tools now needs to be introduced to students. ${ }^{1}$ Even so, the presence of this technology must be able to help the smoothness and optimization of learning developed. Do not let the technology will make the dependence on the perpetrators who do (in this case, the teacher and students). ${ }^{2}$ The existence of technology is the result of human thought that plays a role in helping and reducing difficulties in the course of life. ${ }^{3}$ The PC-Tab device is one of the technology products in the digital era. The apply of this technology in school is still new. Indonesia has started to implement for using digital tools to improve school quality since 2015 ,

1 U.S. Department of Education, "Use of Technology in Teaching and Learning," 2004, https://www.ed.gov/oii-news/use-technology-teaching-and-learning.

2 Ben McNeely, "Using Technology as a Learning Tool, Not Just the Cool New Thing," EDUCAUSE, accessed May 20, 2020, https://www.educause.edu/research-andpublications/books/educating-net-generation/using-technology-learning-tool-not-just-cool-new-thing.

${ }^{3}$ Ron McGivern, "Chapter 8. Media and Technology," in Introduction to Sociology - 2nd Canadian Edition, 2016, https://opentextbc.ca/introductiontosociology2ndedition/chapter/chapter-8-media-andtechnology/. 
despite beginning to pioneer since $2011 .^{4}$ Then, the Indonesia government published the newest policy to support digitalization in education through the Regulation of Ministry of Education and Culture No. 31 of 2019. But, the use of digital tools in Indonesia, such as PC-Tab, is still for several schools, and gradually for all schools. ${ }^{5}$ Besides, a few schools at the city/district level are capable of getting it.

In the beginning, E-Sabak called SabakMoE or Sabak Ministry of Education. The use of SabakMoE is a tool in the learning process for students who integrate with the Learning Management System (LMS). The function of the device is as a tool to help students and teachers access interactive multimedia learning resources, access to learning information systems, schedules, syllabus, curriculum, assignments, assessments, learning outcomes reporting, as well as communication and collaborative devices. But, in the first stage, this tablet is used as an electronic book whose function is to replace the books. ${ }^{6}$

Mathematical learning, one of subject matter in elementary school, needs to be developed in a series of learning processes in a classroom context using a variety of relevant and optimal learning media. One of them is learning mathematics using a PC Tab device, such as use e-sabak to optimize the ability of high-level thinking students in elementary school. The purpose of e-sabak development is to be able to provide direct experience to students in following a series of learning processes in their class. ${ }^{7}$ The series of learning processes using e-sabak still does not leave the essence of learning itself. Learning using e-sabak still requires the development of processes with various methods that can activate and optimize student competencies in the context of an active process approach. Students can observe learning using this tool. Besides, students can carry out the scientific process in each step, also using this tool.

Based on the release released from the results of research funded by UNICEF and carried out by the Ministry of Communication and Information, found a set of evidence that there are around 30 million children and adolescents of Indonesia as active internet

4 Jaka Warsihna, Siti Mutmainah, and Ita Utari, "E-Sabak (Tablet) Untuk Pembelajaran Di Indonesia," Jurnal Teknodik 19, no. 3 (September 29, 2015): 293-304, https://doi.org/10.32550/teknodik.v19i3.171.

5 The Indonesia Ministry of Education and Culture Website Manager, "Digitalisasi Sekolah Percepat Perluasan Akses Pendidikan Berkualitas Di Daerah 3T," Kementerian Pendidikan dan Kebudayaan, October 17, 2019, https:/www.kemdikbud.go.id/main/blog/2019/10/digitalisasi-sekolah-percepatperluasan-akses-pendidikan-berkualitas-di-daerah-3t.

${ }^{6}$ Warsihna, Mutmainah, and Utari, "E-Sabak (Tablet) Untuk Pembelajaran Di Indonesia."

${ }^{7}$ Warsihna, Mutmainah, and Utari. 
users. ${ }^{8}$ Setyawati stated, the existence of these facts indicates that digital media is now the main choice of their communication channels. ${ }^{9}$ All this fact shows that the development of digital technology has brought many changes in society, including in education. Therefore, the education process also needs to integrate the use of technology. Thus, the development in a series of learning methods, especially the content of mathematics teaching in elementary schools, is the use of child-friendly and technologybased devices, one of which is in the form of e-sabak devices..

Many countries in the world have used e-slate as a learning tool. The following states have used e-sabak, such as Jamaica, Brazil, Colombia, the United States, and Peru. Furthermore, the next countries that use e-slate are Japan, Kazakhstan, Turkey, Thailand, India, Singapore, South Korea, China, Mauritius, South Africa, England, and France. Next is Australia. The results of the application of e-slate in various countries show that students enjoy the learning process, can learn independently or collaborate, can be anytime and anywhere, between students or teachers, can communicate with each other, and students are familiar with cellular technology. ${ }^{10}$ A few countries in Southeast Asia also have applied e-sabak. For the Southeast Asian region itself, the first country that has used tablets for education is Thailand. The results of a study conducted by Viriyapong and Harfield stated that the considerations of using tablets for learning are: (1) the ease and comfort to uses, (2) the cost of purchasing and maintaining is cheaper than the cost of computers, (3) children prefer touch screen technology and interactive, and (4) preschool children can learn to use tablets faster. ${ }^{11}$

As Parsons and Oja said in Huber, e-Sabak was a set of freelance computers that use touch screen technology, and its usefulness is for writing and drawing. Deeper stated about the types of tablets, such as tablets as slates (stationery) and devices that resemble laptops. ${ }^{12}$ The use of this tablet is to help the work process of someone under their

\footnotetext{
${ }^{8}$ Didi Purwadi, "Riset: 30 Juta Anak Indonesia Pengguna Internet,” Republika Online, February 18, 2014, https://www.republika.co.id/berita/nasional/umum/14/02/18/n174jc-riset-30-juta-anakindonesiapengguna-internet.

9 Ika Febrian Kristiana et al., "Prosiding Seminar Nasional Psikologi Educational Wellbeing," Prosiding Seminar Nasional Psikologi Educational Wellbeing, 2015, http://eprints.umk.ac.id/4904/10/Full_Prosiding_Semnas_Psi_UMK_2015.106-125.pdf.

${ }^{10}$ Warsihna, Mutmainah, and Utari, "E-Sabak (Tablet) Untuk Pembelajaran Di Indonesia," 294.

${ }^{11}$ Ratchada Viriyapong and Antony Harfield, "Facing the Challenges of the One-Tablet-Per-Child Policy in Thai Primary School Education," International Journal of Advanced Computer Science and Applications (IJACSA) 4, no. 9 (May 30, 2013), https://doi.org/10.14569/IJACSA.2013.040928.

${ }^{12}$ Sabrina Huber, IPads in the Classroom: A Development of a Taxonomy for the Use of Tablets in Schools (Norderstedt: Books on Demand, 2012).
} 
designation. For use in schools, the designation and programs embedded in it are adjusted to the relevant learning material in schools, especially elementary schools.

The use of e-sabak is increasingly popular, especially those in the City of Depok, West Java. However, the use of these devices is still minimal because, based on the existing release, in 2016, only 12 primary and junior high schools were allowed to use the e-slate device package from PT. Telkom Indonesia. The following year (2017), there were already 18 schools that were getting the same opportunity. ${ }^{13}$ One of the schools that received the opportunity was Pondok Petir 01 Public Primary school, Bojongsari, Depok City, West Java. Therefore, this article will describe how the use of e-sabak to optimize the learning process, especially the content of mathematics learning in the school. The purpose of this study is to explain how the use of e-slate in optimizing the learning process of mathematics learning content in the fourth grade of SDN Pondok Petir 01, Bojongsari, Depok City, West Java.

The purpose of this study was to explain the implementation of Mathematics learning in optimizing the ability to think at a higher level a higher level (HOTS) through the use of e-sabak devices in fourth grade SDN Pondok Petir 01, Depok City. The scope of the research is about the process of walking in practical mathematics learning steps. The research context was in a specific classroom. This classroom design was to optimize the ability to think at a higher level. Meanwhile, the digital tool for optimizing student's HOTS was e-sabak devices. Students and teachers in the fourth grade of SDN Pondok Petir 01, Depok City apply e-sabak for Mathematic learning.

\section{RESEARCH METHODS}

The research process aims to capture descriptive data related to the use of e-sabak in optimizing the ability to think at a high level in mathematics learning at SDN Pondok Petir 01, Depok City, West Java. The research approach used is through a qualitative approach with descriptive methods to describe the process of learning mathematics through the use of e-sabak to optimize the ability to think at the high level of fourth-grade students at SDN Pondok Petir 01, Depok City. The data collection technique applied interviews, observations, and documentation.

13 Rusdy Nurdiansyah, "E-Sabak Sekolah Pelopor Pembelajaran Berbasis Teknologi," Republika Online, 2019, https://republika.co.id/berita/nasional/jabodetabek-nasional/pxpbo9396/esabak-sekolahpelopor-pembelajaraan-berbasis-teknologi. 
A qualitative approach is a research procedure that produces descriptive data in the form of speech or writing and behavior from the subject itself. ${ }^{14}$ A qualitative approach is a research approach to explore and understand phenomena that occur to individuals in the social sphere. The researcher used this approach to identify and raise individual issues in the social context in order to develop strategic steps in the improvement and standard of living of a social environment in the community itself. Nevertheless, this approach is not only limited to social problems, but it is also able to raise the issue of individuals who are members of certain social groups.

The implementation of this research was a period of 3 months, namely from July to September 2019. The research location was in fourth grade of SDN Pondok Petir 01, Depok City, located on Reni Jaya Selatan Street, Pondok Petir, Bojongsari, Depok City, West Java. One of the essential things in research is research data because, through data, various kinds of research objectives can be achieved, both in terms of answering questions and testing hypotheses. ${ }^{15}$ Therefore, the data collection step can be said to be one of the essential steps in research. Research data is the result of observations and measurements made empirically, which reveal facts about the characteristics of a particular symptom. In the research process, researchers do not just rely on rational knowledge alone, because often what is seen or heard every day is different from the reality on the ground. Therefore it is vital to search for and find facts as empirical knowledge through data collection.

The method of recording data in this study used two primary ways, namely, direct observation and documentation. The purpose of both ways was as a control step to obtain objective data and to avoid data bias. The collecting data through a process of observation, documentation, and interviews with teachers and students involved in a series of learning methods for the content of mathematics teaching in the fourth grade of SDN Pondok Petir 01, Depok City. In the process, the researchers documented using a camera to obtain image data from a series of learning processes carried out through the use of e-sabak to optimize the ability of high-level thinking in mathematics learning of fourth-grade students at SDN Pondok Petir 01, Depok City.

Post-obtained data, the next process was to analyze the data according to the type of data obtained in this research process series. Qualitative data analysis is an effort made

${ }^{14}$ John W. Creswell, Research Design: Qualitative, Quantitative, and Mix Methods Approaches, 3rd ed. (California: SAGE Publication, Inc., 2009), 12.

${ }^{15}$ Ulber Silalahi, Metode Penelitian Sosial (Bandung: UNPAR Press, 2006), 257. 
through a series of work with data, organizing data, breaking it down into manageable units, synthesizing it, searching and finding patterns, discovering what is essential and what is learned, and deciding the research conclusion. ${ }^{16}$ The analysis is a study to look for patterns. The design here refers to cultural trends, not merely the social situation of a cultural domain, which is a category of cultural meaning that involves smaller groups.

Data analysis carried out during data collection brings researchers pacing between thinking about existing data and developing strategies for collecting new data. In the process, corrections were also made to unclear information and directed the ongoing analysis relating to the impact of the generation of fieldwork. The steps taken in data collection are a compilation of contact summary sheets, making codes, coding patterns, and giving memos.

The data analysis process was three sets, namely, (1) open coding, (2) axial coding, and (3) selective coding. Open coding is by identifying categories, properties, and dimensions. As for the axial coding step is the process of developing relationships between classes in data research. In selective coding, selection of the most basic types systematically links them to other groups and validates the relationship.

\section{RESULT AND DISCUSSION}

The development of the mathematics learning process in the fourth grade of SDN Pondok Petir 01, Depok City, during the period of research, always sought to use the esabak device. The e-sabak tool is a learning aid that plays a role in making it easier for students to optimize their high-level thinking skills. However, the teacher seeks to always provide learning experiences to students through observations and workflows that lead to the presentation of group work after making a series of observations in the field related to mathematics learning material that students learn at that time. The development of a set of mathematics learning is as a single independent lesson. This design is different from other lesson content design. Mathematic learning design is a design based subject matter. Meanwhile, the model for other subject utilizes one thematic form of integrated learning in fourth grade.

${ }^{16}$ Robert Bogdan and Sari Knopp Biklen, Qualitative Research for Education: An Intruduction to Theory and Methods (Boston: Allyn and Bacon, 1982), 172. 
Based on a series of observations, documentation, and interviews conducted before learning using e-sabak, the team gave a briefing to all teachers and students in fourth grades through fifth grades. The team came from a vendor that provided an e-sabak device, Telkom Indonesia Ltd. Co. Figure 1 shows the flow of assistance from the vendor.

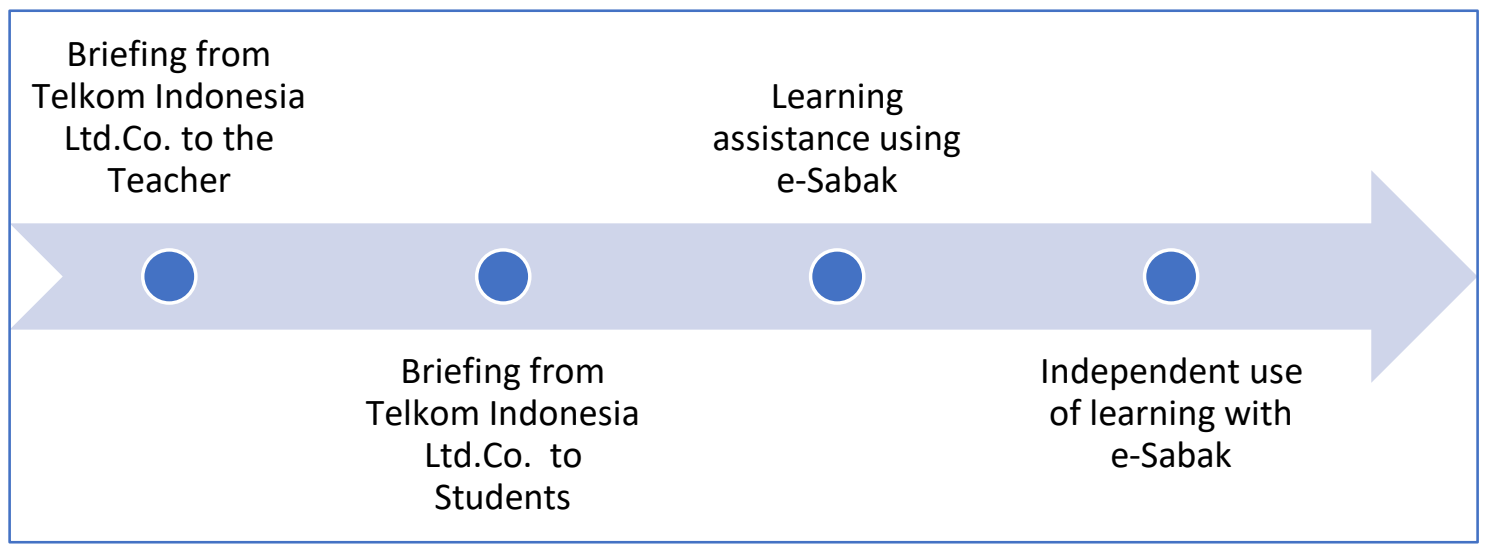

Figure 1

The flow of the debriefing and mentoring of e-sabak activities in learning

This program got the assistance process for two months in the beginning. The teachers who received debriefing were 25 teachers at SDN Pondok Petir 01, Depok City. The students involved in the initial debriefing were each 1 class in grades IV through VI, with an average number of 32 to 38 students in one class. Although not all classes in fourth grades to fifth grades receive direct training by the vendor, all classes also use the e-sabak tool in the learning developed. Namely, by giving flexibility to each class teacher to be able to take advantage of the e-sabak device in learning.

In the process of providing tools and initial assistance, Telkom does not release directly when the teacher uses e-sabak in the learning process. The teacher needs to notify a week in advance that a schedule for use and assistance with Telkom Indonesia Ltd. Co. In their praxis for five times of mentoring (in two months), there were two times the vendor could not assist because the schedule changed suddenly. The reason was the team also had a program at another school. In the debriefing process by the vendor team, there are still teachers who cannot attend or can attend but cannot fully participate and follow through to completion. 


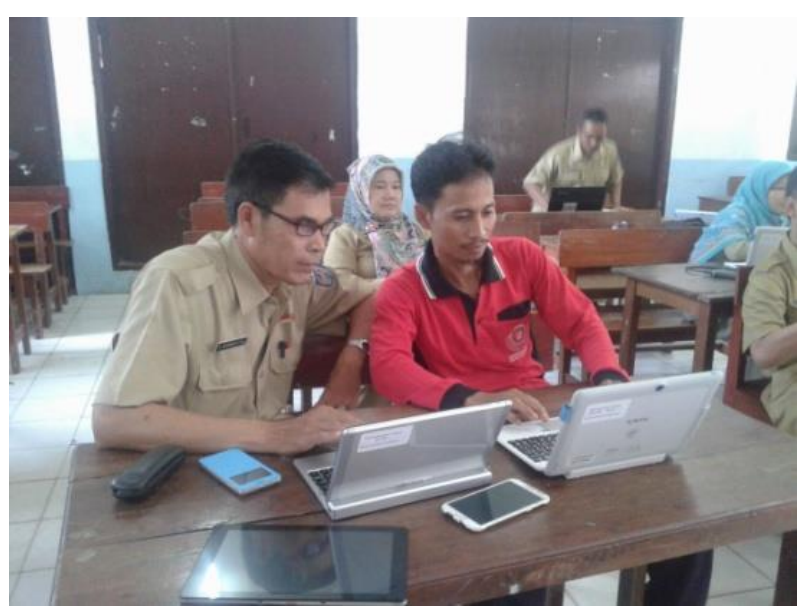

Figure 2

The first debriefing activity to teachers by a team from Telkom Indonesia Ltd. Co.

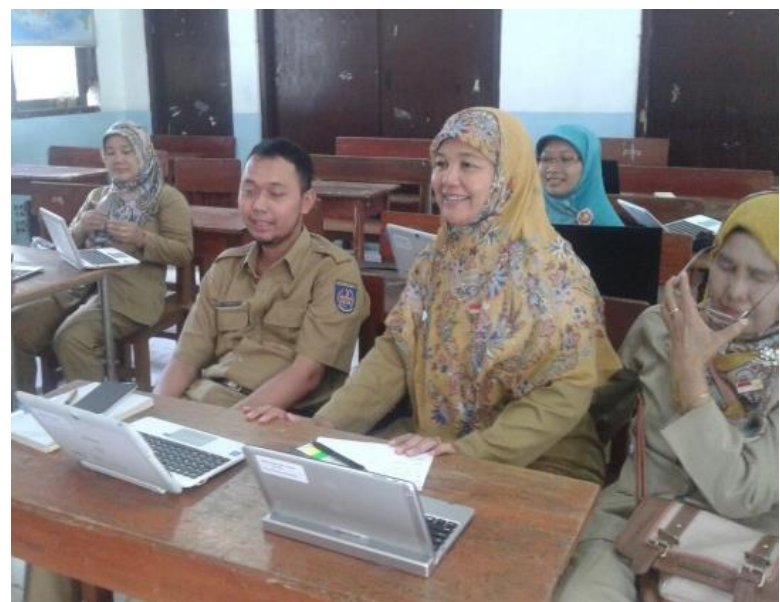

Figure 3

The second debriefing activity to the teacher by a team from Telkom Indonesia, Ltd. Co.

The implementation of the debriefing activities was during a period of 2 months. The execution was every two weeks scheduled every Monday or Wednesday. The aim of the debriefing process was for the teacher is able both praxis and conceptually how to use e-sabak tools in learning. In this case, the main objective here is how the teacher can develop innovative learning sequences through the use of e-sabak devices in the classroom. Thus, learning activities can produce achievements on target.

The students also do debriefing activities. Then, technically a team from PT. Telkom Indonesia continued these activities. In the process, the group experienced a few obstacles because it was unable to control the class. However, the teacher in the class was swiftly able to control the atmosphere so that the activities could resume smoothly and as expected. 


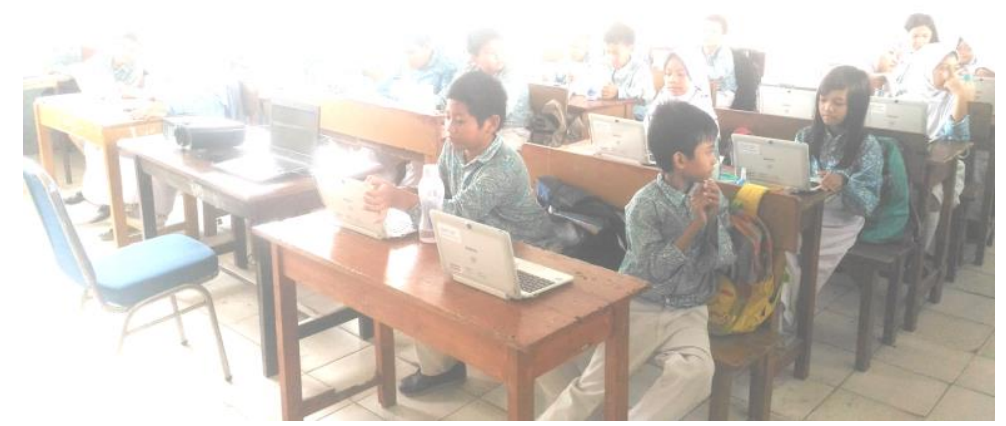

Figure 4

E-sabak provisioning activities for students by a team from Telkom Indonesia Ltd. Co.

The execution of assistance activities was in the same format as the debriefing activities. However, the vendor team acts more like an observer in developing the learning process. In the process, the teacher chooses and determines the learning material.

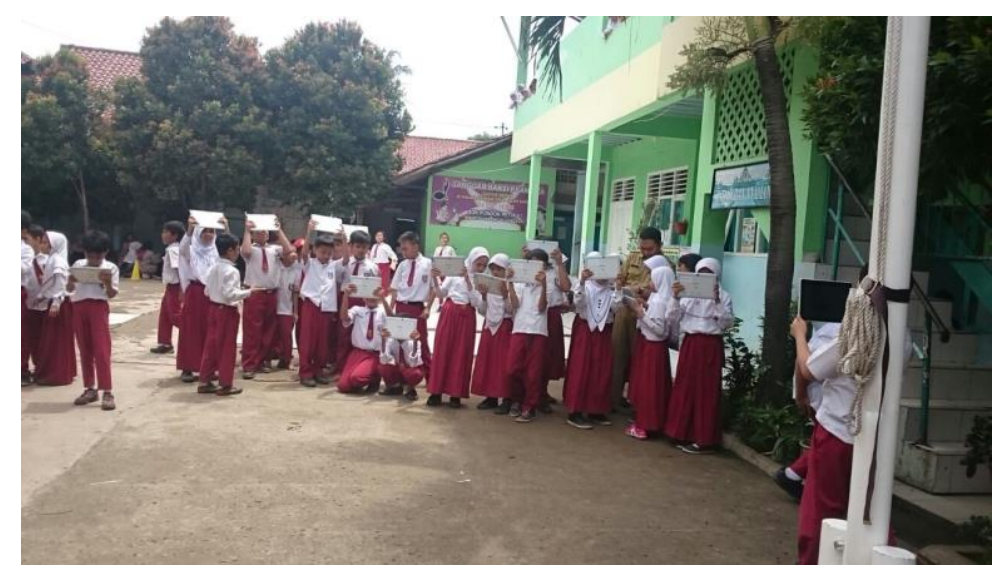

Figure 5

The student does observation activities in a series of learning mathematics content using e-sabak

The e-sabak device used consisted of several instruments, including: (1) a student's Tab PC; (2) Teacher's PC Tab; (3) Projector LCD; (4) camera equipment; (5) internet connection with LAN cable; (6) local server. The devices have a connection systemically in a 24-hour. Besides, the devices have assistation with supervision using a 3600 camera device. However, the focus in this study is how to use e-sabak in optimizing high-level thinking skills in mathematics learning in the fourth grade of SDN Pondok Petir 01, Depok City. Here, researcher uncover and document and identify that e-sabak devices as innovative technology-based media can optimize the ability of high-level thinking in mathematics learning in classroom contexts. Thus, e-sabak as a learning tools, 
can improve the result of mathematic learning quality, especially the student's higherorder thinking skills.

The process of learning mathematics by using e-sabak devices can optimize the ability to think at a higher level according to the learning material. In the development of learning design, the teacher gave students limited time in mathematics learning time in the morning. The teacher gave the task to calculate the distance and time taken by students who are practicing relay running in the field. Students in groups divide and organize themselves to observe a group that is practicing the relay race. Of all students who have carried out the relay practice, the teacher asked each group to calculate the total amount of travel time achieved to then conclude which group was the fastest and what things influenced it.

The findings of this study reinforce Yang's research findings, which revealed that digital game-based learning was significantly able to improve three higher-order thinking skills, namely: (1) creative thinking skills, (2) critical thinking skills, and (2) problemsolving skills. ${ }^{17}$ This study also corroborates the findings of Carolyn Chang and Yang, who also found that digital game-based learning can improve critical thinking skills, academic achievement, concentration, and student participation. ${ }^{18}$ However, the findings of this study are to be different from Edwards's research findings which conducted a study of the role of technology in learning to improve high-level thinking skills of high school students in arts and English classes. Edward's findings reveal that the existence of technology does not necessarily automatically be able to foster higher-order thinking skills of students. The existence of technology in learning to improve students' critical thinking skills must be on the condition that there is a teacher who is confident in the use of technology and has an intelligent awareness of the limitations and potential of technology. ${ }^{19}$ Thus, the findings of this study help strengthen previous findings that the

${ }^{17}$ Ya-Ting Carolyn Yang, "Virtual CEOs: A Blended Approach to Digital Gaming for Enhancing Higher Order Thinking and Academic Achievement among Vocational High School Students," Computers \& Education 81 (February 1, 2015): 281-95, https://doi.org/10.1016/j.compedu.2014.10.004.

${ }_{18}$ Ya-Ting Carolyn Yang and Chao-Hsiang Chang, "Empowering Students through Digital Game Authorship: Enhancing Concentration, Critical Thinking, and Academic Achievement," Computers \& Education 68 (October 1, 2013): 334-44, https://doi.org/10.1016/j.compedu.2013.05.023.

${ }^{19}$ Lucy Edwards, Education, Technology and Higher Order Thinking Skills, Australian Association for Research in Education (Australian Association for Research in Education, 2016), https://eric.ed.gov/?id=ED591857. 
existence of technology in learning can improve student's high-level thinking skills, but must have the support of competent and professional teacher resources.

\section{CONCLUSION}

The finding of the research is the learning activities using the e-sabak device are carried out independently by the teacher, and students in the class can optimize the higherorder thinking skills. In the learning process, students alone use the one-student e-sabak tool so that they feel directly utilizing this device in the learning process. The stages of the use of instructional media are not directly used in the classroom but are preceded by debriefing and training conducted directly by the vendor team (in this case, PT. Telkom Indonesia). Stages of debriefing carried out are for 4 steps, including (1) debriefing to teachers by Telkom Indonesia Ltd. Co.; (2) debriefing to students by the Team of Telkom Indonesia Ltd.Co.; (3) assisting in the use of e-sabak in learning by the Team of Telkom Indonesia Ltd. Co.;; (4) the independent use of e-sabak devices in classroom learning by the teacher under the monitoring of the Team of Telkom Indonesia Ltd.Co.

The development of the series of mathematics learning processes in the fourth grade of SDN Pondok Petir 01, Depok City, West Java, was during 2 months running. The overall time needed in this study is three months, with one month used is for the preparation and development of observation instruments. In the process, learning is done by referring to the study of conceptual material that students will learn in class. After obtaining relevant content that can be developed, the steps of learning are developed by including the use of e-sabak tools in the teaching that is carried out. Besides, the learning steps that are practiced in the learning plan are developed to be able to optimize the dimensions of higher-order thinking skills. Each of these learning steps must contain at least three aspects of higher-order thinking skills. Some learning steps that are implemented also must pour operational praxis on student activities to analyze, evaluate, and create various problem contexts presented in mathematics learning in fourth grade.

In the process, students do the learning process in several locations that are determined. Learning begins with an understanding of the material to be developed in the classroom. Furthermore, students make observations and data acquisition by photographing and observing the specified activities (in this case the subjects of class VI students who are practicing relay running). The execution of these activities was for 
students need to observe and obtain empirical data related to the time required for each team to complete one relay cycle to identify the fastest team then and conclude why the team was able to be the fastest in the activity. Furthermore, students utilize the existing environment (other than in the classroom) to discuss in groups what they get in the field. The last activity carried out was that students in groups presented their observations in the area based on the group discussions.

\section{REFERENCES}

Bogdan, Robert, and Sari Knopp Biklen. Qualitative Research for Education: An Intruduction to Theory and Methods. Boston: Allyn and Bacon, 1982.

Carolyn Yang, Ya-Ting, and Chao-Hsiang Chang. "Empowering Students through Digital Game Authorship: Enhancing Concentration, Critical Thinking, and Academic Achievement." Computers \& Education 68 (October 1, 2013): 334-44. https://doi.org/10.1016/j.compedu.2013.05.023.

Creswell, John W. Research Design: Qualitative, Quantitative, and Mix Methods Approaches. 3rd ed. California: SAGE Publication, Inc., 2009.

Edwards, Lucy. Education, Technology and Higher Order Thinking Skills. Australian Association for Research in Education. Australian Association for Research in Education, 2016. https://eric.ed.gov/?id=ED591857.

Huber, Sabrina. IPads in the Classroom: A Development of a Taxonomy for the Use of Tablets in Schools. Norderstedt: Books on Demand, 2012.

Kristiana, Ika Febrian, Yeni Triwahyuningsih, Beatriks novianti Bunga, indra yohanes kiling, dwi wahyuning Setiyorini, Akmalia Istinadya, Desy Ayunungsih, et al. "Prosiding Seminar Nasional Psikologi Educational Wellbeing." Prosiding Seminar Nasional Psikologi Educational Wellbeing, 2015. http://eprints.umk.ac.id/4904/10/Full_Prosiding_Semnas_Psi_UMK_2015.106125.pdf.

McGivern, Ron. "Chapter 8. Media and Technology." In Introduction to Sociology - 2nd Canadian Edition, 2016. https://opentextbc.ca/introductiontosociology2ndedition/chapter/chapter-8-mediaand-technology/.

McNeely, Ben. "Using Technology as a Learning Tool, Not Just the Cool New Thing." EDUCAUSE. Accessed May 20, 2020. https://www.educause.edu/research-andpublications/books/educating-net-generation/using-technology-learning-tool-notjust-cool-new-thing.

Nurdiansyah, Rusdy. "E-Sabak Sekolah Pelopor Pembelajaran Berbasis Teknologi." Republika Online, 2019. https://republika.co.id/berita/nasional/jabodetabeknasional/pxpbo9396/esabak-sekolah-pelopor-pembelajaraan-berbasis-teknologi.

Purwadi, Didi. "Riset: 30 Juta Anak Indonesia Pengguna Internet.” Republika Online, February 
https://www.republika.co.id/berita/nasional/umum/14/02/18/n174jc-riset-30-jutaanakindonesia-pengguna-internet.

Silalahi, Ulber. Metode Penelitian Sosial. Bandung: UNPAR Press, 2006.

The Indonesia Ministry of Education and Culture Website Manager. "Digitalisasi Sekolah Percepat Perluasan Akses Pendidikan Berkualitas Di Daerah 3T." Kementerian $\begin{array}{llll}\text { Pendidikan dan } \quad \text { Kebudayaan, } & \text { October }\end{array}$ https://www.kemdikbud.go.id/main/blog/2019/10/digitalisasi-sekolah-percepatperluasan-akses-pendidikan-berkualitas-di-daerah-3t.

U.S. Department of Education. "Use of Technology in Teaching and Learning," 2004. https://www.ed.gov/oii-news/use-technology-teaching-and-learning.

Viriyapong, Ratchada, and Antony Harfield. "Facing the Challenges of the One-TabletPer-Child Policy in Thai Primary School Education." International Journal of Advanced Computer Science and Applications (IJACSA) 4, no. 9 (May 30, 2013). https://doi.org/10.14569/IJACSA.2013.040928.

Warsihna, Jaka, Siti Mutmainah, and Ita Utari. "E-Sabak (Tablet) Untuk Pembelajaran Di Indonesia." Jurnal Teknodik 19, no. 3 (September 29, 2015): 293-304. https://doi.org/10.32550/teknodik.v19i3.171.

Yang, Ya-Ting Carolyn. "Virtual CEOs: A Blended Approach to Digital Gaming for Enhancing Higher Order Thinking and Academic Achievement among Vocational High School Students." Computers \& Education 81 (February 1, 2015): 281-95. https://doi.org/10.1016/j.compedu.2014.10.004. 
The Use of E-Sabak...

124| Al-Bidayah, Volume 12, Number 1, June 2020 